\title{
Acupuncture and percutaneous electric nerve stimulation to control chronic masticatory myalgia: preliminary study*
}

\author{
Uso da acupuntura e da estimulação elétrica nervosa percutânea no controle da mialgia \\ mastigatória crônica: estudo preliminar
}

Cyntia de Medeiros Nogueira ${ }^{1}$, Michele Gomes do Nascimento ${ }^{1}$, Andreana Braga de Morais Malouf ${ }^{1}$, Maria do Socorro Catanho Pereira de Lyra Didier ${ }^{1}$, Arnaldo de França Caldas Júnior ${ }^{1}$, Mauricio Kosminsky ${ }^{1}$

${ }^{*}$ Received from University of Pernambuco, School of Dentistry, Recife, PE, Brazil.

DOI 10.5935/1806-0013.20150032

\section{ABSTRACT}

BACKGROUND AND OBJECTIVES: This was a randomized clinical trial to compare the analgesic effect of acupuncture and percutaneous electric nerve stimulation for chronic masseter muscle masticatory myalgia.

METHODS: Participated in the study 23 patients with unilateral or bilateral masticatory myalgia, who were selected according to Research Diagnostic Criteria for Temporomandibular Disorders and were distributed in two groups. Acupuncture and percutaneous electric nerve stimulation groups were made up of 12 and 11 patients, respectively. In each group, patients were submitted to two weekly treatment sessions lasting 20 minutes, in a total of 9 sessions. Selected points for the acupuncture group were IG4, E36, F3, ShemMen (bilateral auricular), VG20 and Yintang. Needles were inserted and stimulated until “De Qi” was obtained, then remaining without stimulation until procedure completion. In the electric stimulation group, symptomatic points were identified by manual palpation and electric stimulation was applied. Both groups have described pain intensity by means of the visual analog scale, before the first, fifth and ninth sessions. Results were evaluated with Student $t$ and F (ANOVA) tests.

RESULTS: There has been mean visual analog scale scores decrease in both groups at each measurement, being that in the last measurement the acupuncture group had statistically lower mean as compared to the percutaneous electric nerve stimulation group. CONCLUSION: Acupuncture and percutaneous electric nerve stimulation are effective methods to improve masseter muscle masticatory myalgia in the short term.

Keywords: Acupuncture, Percutaneous electric nerve stimulation, Temporomandibular disorders.

1. Universidade de Pernambuco, Faculdade de Odontologia, Recife, PE, Brasil.

Submitted in February 19, 2015.

Accepted for publication in July 16, 2015.

Conflict of interests: none - Sponsoring sources: none.

Correspondence to:

Maurício Kosminsky

Centro de Controle da Dor Orofacial, Faculdade de Odontologia de Pernambuco

Av. General Newton Cavalcanti, 1650

54753-220, Camaragibe, PE, Brasil.

E-mail: socyntia@yahoo.com.br

(c) Sociedade Brasileira para o Estudo da Dor

\section{RESUMO}

JUSTIFICATIVA E OBJETIVOS: Foi conduzido um ensaio clínico randomizado, com o objetivo de comparar o efeito analgésico da acupuntura com a estimulação elétrica percutânea na mialgia mastigatória crônica no músculo masseter.

MÉTODOS: Vinte e três pacientes com mialgia mastigatória uni ou bilateral foram selecionados, segundo os Critérios de Diagnóstico em Pesquisa para Desordens Temporomandibulares, e distribuídos em 2 grupos. Os grupos acupuntura e estimulação elétrica percutânea foram constituídos de 12 e 11 pacientes, respectivamente. Em cada grupo, os pacientes foram submetidos a duas sessóes semanais de tratamento com duração de $20 \mathrm{~min}$, totalizando 9 sessóes. No grupo acupuntura, os pontos selecionados foram IG4, E36, F3, ShemMen (auricular bilateral), VG20 e Yintang. As agulhas foram inseridas e estimuladas até a obtenção do "De Qi", permanecendo sem estimulação adicional até o final do procedimento. No grupo estimulação elétrica percutânea, os pontos sintomáticos foram identificados à palpação manual e o estímulo elétrico foi aplicado. Ambos os grupos descreveram a intensidade da dor por meio da escala analógica visual, antes da primeira, quinta e nona sessóes. Os resultados foram avaliados por meio dos testes $t$ de Student e F (ANOVA).

RESULTADOS: Houve redução da média dos valores da escala analógica visual em ambos os grupos a cada aferição, sendo que na última o grupo acupuntura apresentou média estatisticamente inferior ao grupo estimulação elétrica percutânea.

CONCLUSÃO: A acupuntura e a estimulação elétrica percutânea são métodos eficazes na redução da mialgia mastigatória do músculo masseter no curto prazo.

Descritores: Acupuntura, Desordens temporomandibulares, Estimulação elétrica nervosa percutânea.

\section{INTRODUCTION}

Masticatory myalgia (MM) is deep somatic pain, characterized by fatigue or pain worsened by jaw passive or functional movement, which may limit mouth opening ${ }^{1}$.

There is controversy about the most adequate therapeutic approach to control MM. Recommendations include a wide variety of procedures including rest, thermal therapy, stretching, exercises, massage, acupressure, intervention on tri- 
gger-points (TP), behavioral therapy, occlusal splints, drugs and placebo $^{2}$. Pharmacological therapies, such as muscle relaxants and antidepressants, have been widely applied to control such myalgias ${ }^{3}$, however they have adverse effects. There is currently increasing interest on neuromodulating therapies, such as acupuncture and electric therapy modalities, such as percutaneous electric nerve stimulation (PENS).

Acupuncture is part of integrative and complementary treatment practices recognized by the World Health Organization (WHO). This therapy has been used to control different types of pain, with a safety pattern that makes it adequate for clinical practice $e^{4}$. Recent advances in the establishment of control groups for acupuncture have allowed the design of more reliable studies 5 . Acupuncture improves signs and symptoms associated to temporomandibular disorders ${ }^{6}$, and increases pain tolerance threshold of the masseter muscle ${ }^{7}$.

PENS is considered a new electroanalgesia modality, with the therapeutic advantages of transcutaneous electric nerve stimulation (TENS) and of electroacupuncture ${ }^{8,9}$. It consists in inserting acupuncture needles associated to bipolar electric conduits in the region of the dermatome corresponding to the source of pain ${ }^{9,10}$. PENS is effective to control pain in the short ${ }^{11}$ and long term, with possible cumulative analgesic effect during application sessions ${ }^{12}$.

This study aimed at comparing the analgesic effect of PENS on MM.

\section{METHODS}

The study was developed in the Orofacial Pain Control Center, School of Dentistry, University of Pernambuco, according to principles of Resolution 466/2012 of the National Health Council, Department of Health, and in compliance with the Declaration of Helsinki. Population was made up of spontaneous or referred demand, aged between 22 and 64 years, with MM. Participation was made effective by free and sovereign will through the reading and signing of the Free and Informed Consent Term (FICT).

Inclusion criteria were pain for more than three months, of muscular origin and unilaterally or bilaterally affecting the masseter muscle; ability to read, understand and cooperate with the clinical evaluation of the Research Diagnostic Criteria for Temporomandibular Disorders (RDC/TMD) and visual analog scale (VAS). Exclusion criteria were patients with intra-articular disorders; history of facial trauma; reported pain of high intensity suggesting the need for pharmacological control; pregnancy, epilepsy or cardiac pace-maker; history of malignant tumors; orofacial tissue infection; presence of dysesthesia at intervention site; totally edentulous without oral rehabilitation.

In a first screening we have selected among orofacial pain (OFP) patients those with symptoms related to temporomandibular disorders (TMD) for more than three months, using the Simplified Anamnesis Questionnaire ${ }^{13}$. Then, those meeting inclusion criteria were examined by an investigator qualified to apply RDC/TMD and blind to the experiment ${ }^{14}$, being selected $\mathrm{MM}$ patients. Groups were randomized to acupuncture group (AG) $(\mathrm{n}=12)$ and PENS group $(\mathrm{PG})(\mathrm{n}=11)$.

\section{INTERVENTION}

Patients of both groups were asked to discontinue any symptoms-controlling drug two days before the experiment ${ }^{15}$. For both groups, treatment consisted of two weekly sessions, for five weeks, lasting 20 minutes each, counted as from selected points stimulation, in a total of 9 sessions. Any type of communication different from intervention-related issues was avoided between investigator and patient.

For AG, intervention protocol was developed as from literature reviews and clinical experience ${ }^{16,17}$ by a dentist qualified in acupuncture by the Federal Council of Dentistry with seven years of experience. Selected points were IG4, E36, F3 and Shem Men (bilateral auricular), VG20 and Yintang, all systemic points and far from the pain site, in an attempt to avoid dry TP needling of the masseter muscle. Those points were chosen due to their action on chronic pain control and symptoms commonly associated to TMD, such as anxiety, emotional stress and depression. Application sites were previously cleaned with $70 \%$ alcohol and disposable needles $(0.25 \times 30 \mathrm{~mm})$ were inserted at 10 to $20 \mathrm{~mm}$ depth. In all patients needles were initially stimulated to reach "De Qi" and remained inserted without stimulation until the end of the session.

For PG, a different investigator has selected the areas of electric stimulation application according to painful points, identified by manual palpation with approximately $1 \mathrm{kmf} /$ $\mathrm{cm}^{2}$ digital pressure. Before the procedure, all patients were submitted to proprioception test which, if negative, would impair the adjustment of electric stimulation intensity for PENS, in addition to masking digital pressure inspection result ${ }^{18}$. The device was DIAN-E, NKL brand, gauged by the Institute São Paulo. Protocol consisted in the introduction of two acupuncture needles $(0.20 \times 13 \mathrm{~mm})$ perpendicular to the muscle, and a needle inserted in the painful point and the other $1 \mathrm{~cm}$ of it, with depth of 10 to $13 \mathrm{~mm}$ compatible with the volume of the involved muscle and with adequate stabilization of each needle. Electric stimulation parameter was pulse frequency of $100 \mathrm{~Hz}$, continuous pulse pattern and bidirectional symmetric rectangular pulse shape. Current intensity was tailored according to the tolerance of each patient ${ }^{19}$, being increased to produce the most intense and tolerable electric sensation.

Participants of both groups would describe pain intensity by means of 10-cm VAS, without numbers and with the words no pain and worst imaginable pain on both ends, by means of the question: "What is the pain felt right now?" Answers were measured by an investigator blind to treatment sessions. Due to the possibility of symptoms due to needling interventions, it was established that measurements would be carried out before the first session and immediately before the fifth and ninth (last) interventions. So, for data collection purposes, we 
have totaled evaluation and results related to eight treatment sessions, because in the ninth application session pain intensity was measured only before the procedure.

\section{Statistical analysis}

Data analysis has generated absolute distribution of mean statistical measurements and standard deviation (descriptive statistics), and the following statistical tests were used: Student $t$ with equal variances and $\mathrm{F}$ test (ANOVA) to check equality of variances between groups, with Bonferroni correction (inferential statistics) among measurements. Statistical calculations were made with the program Statistical Package for the Social Sciences, version 15, and error margin for statistical tests decision was $5.0 \%$.

This study was approved by the Ethics Committee, University of Pernambuco under n. 080/2007.

\section{RESULTS}

From 190 patients initially evaluated with OFP, 103 had TMD and in 52 the masseter muscle was unilaterally or bilaterally involved. From these, 23 were randomized in two groups, $A G=12$ and $P G=11$ (Figure 1). One GP patient and two AG patients were lost due to abandonment and report of VAS $=10$, both during the experiment. Age mean and standard deviation for AG was 40.60 and 14.26 years, respectively, and for PG it was 37.10 and 8.17 years. Table 1 shows socio-demographic data of the studied population.

Mean VAS values used for pain measurement are shown in table 2.

Taking as reference the first measurement, where mean values are statistically similar by Student $t$ test, there has been significant mean VAS decrease in further measurements for both groups by the $\mathrm{F}$ test (ANOVA). By means of Bonferroni correction, these differences were located between the first and the second and between the first and the third measurements.

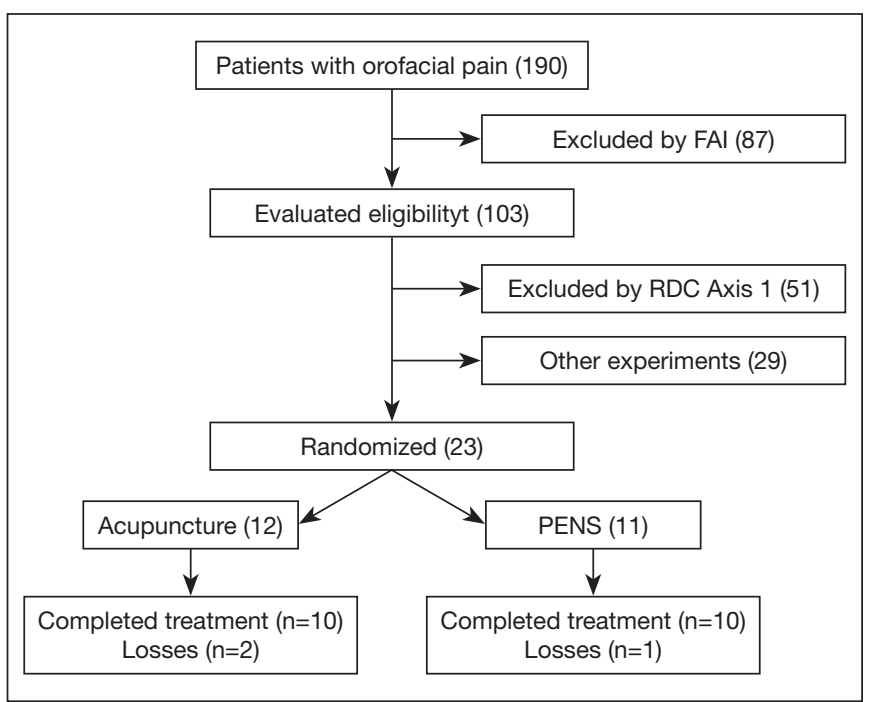

Figure 1. Flowchart of sample distribution

$\mathrm{RDC}=$ Research Diagnostic Criteria; PENS = percutaneous electric nerve stimulation; FAI = Fonseca's Anamnesis Index.
Table 1. Socio-demographic data of both groups

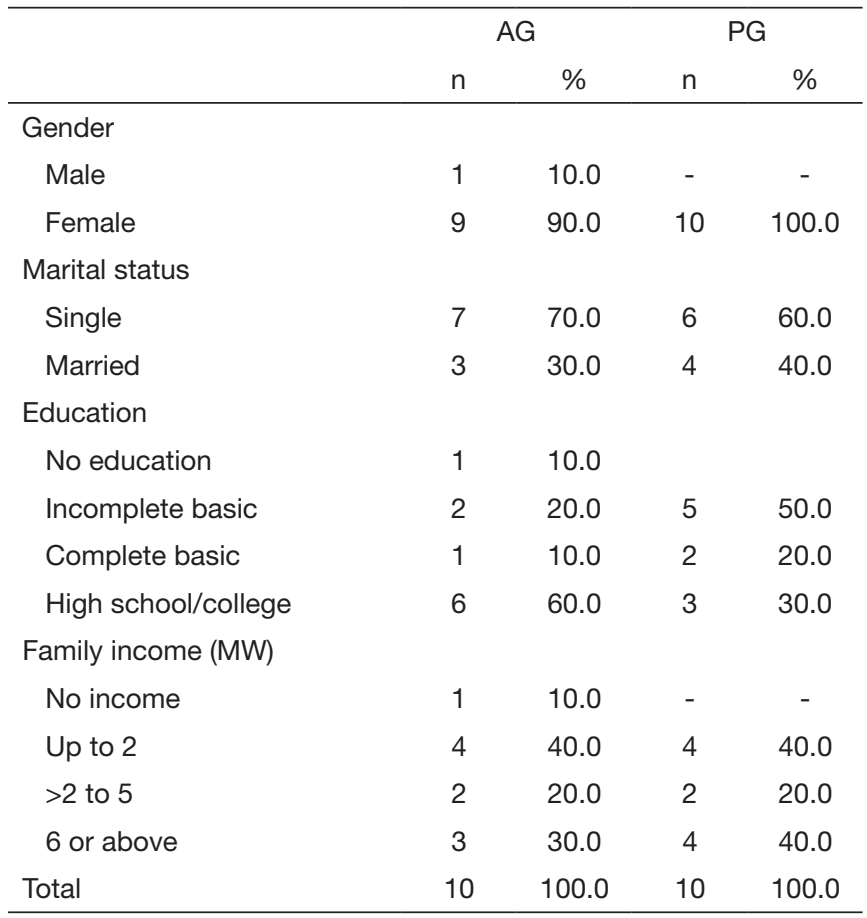

$\overline{\mathrm{AG}}=$ acupuncture group; $\mathrm{PG}=$ percutaneous electric nerve stimulation; $\mathrm{MW}=$ minimum wage.

Table 2. Visual analog scale mean and standard deviation by measurement according to group

\begin{tabular}{lccc}
\hline Measurement & $\mathrm{AG}$ & $\mathrm{PG}$ & $\mathrm{p}$ value \\
\hline \multirow{3}{*}{$1^{\text {st }}$} & Mean $\pm \mathrm{SD}(1)$ & Mean $\pm \mathrm{SD}(1)$ & \\
$2^{\text {nd }}$ & $5.60 \pm 1.65(\mathrm{~A})$ & $6.50 \pm 1.84(\mathrm{~A})$ & $\mathrm{p}(2)=0.264$ \\
$3^{\text {rd }}$ & $1.34 \pm 1.57(\mathrm{~B})$ & $2.74 \pm 2.06(\mathrm{~B})$ & $\mathrm{p}(2)=0.105$ \\
& $0.69 \pm 0.94(\mathrm{~B})$ & $1.80 \pm 1.25(\mathrm{~B})$ & $\mathrm{p}(2)=0.038^{*}$ \\
& $\mathrm{p}(3)<0.001^{*}$ & $\mathrm{p}(3)<0.001^{*}$ & \\
\hline
\end{tabular}

$\mathrm{AG}=$ acupuncture group; $\mathrm{PG}=$ percutaneous electric nerve stimulation.

* Significant difference at 5.0\%; (1) SD= standard deviation; (2) Student $t$ with equal variances; (3) F test (ANOVA) for repeated measures. Means followed by equal letters are not significantly different at $5 \%$.

There has been no statistically significant difference in the last measurement in mean VAS value between AG and PG (Student $t$ test). There has been no relevant intervention-related adverse effect in both groups. Two AG patients have referred mild sedation during intervention.

\section{DISCUSSION}

Neuromodulating therapies seem to have satisfactory results to relief musculoskeletal pain ${ }^{5-7,10,16,17}$. In our study, results have shown decrease of symptoms intensity in groups AG and PG, being that AG patients had mean values statistically lower than PG in the last measurement.

It has been suggested that PENS has a cumulative effect during treatment, perceived by the maintenance of the analgesic effect at each intervention ${ }^{12}$. This fact may be considered in the results of our study, translated into decreased VAS at each 
measurement in the first, third and last treatment weeks. Although PENS being considered a new therapeutic modality $^{9}$, it does not seem to differ, in practice and principles, from electroacupuncture ${ }^{19}$, except with regard to application points. In our study, sites to place needles in PG were points corresponding to the source of pain reported by patients and confirmed by physical evaluation. For AG, chosen puncture points were systemic acupuncture points located distant from the pain site. It has been shown that acupuncture points often coincide with common symptomatic regions of masticatory muscles. Point E7, for example, corresponds to the location of a latent TG in the masseter region, reported by several individuals with facial pain. So, one should not discard the possibility that part of pain relief in PG could be effect of the simple puncture of acupuncture points in the muscle, and not of the electric stimulation.

Both techniques were effective to control short term pain in $\mathrm{AG}$ and $\mathrm{PG}^{7,11}$ Acupuncture had differentiated results when compared to placebo without needle insertion, suggesting clinically significant neuromodulating mechanisms as consequence of the puncture ${ }^{17}$. This neuromodulating therapy was effective, in the short term, to decrease TMD-related pain of muscular origin ${ }^{16}$, confirming the results of this study.

The difficulty to select patients exclusively with masseter muscle MM has determined a small sample. Future studies with larger samples may consistently confirm our results.

\section{CONCLUSION}

Acupuncture and PENS have decreased, in the short term, reported symptoms of chronic masticatory myalgia in the masseter muscle, being that AG had further symptoms intensity decrease as compared to the PENS group.

\section{REFERENCES}

1. Dworkin SF, LeResche L. Research diagnostic criteria for temporomandibular disorders: review, criteria, examinations and specifications, critique. J Craniomandib Di- sord. 1992;6(4):301-55.

2. Manfredini D, Landi N, Tognini F, Orlando B, Bosco M. Muscle relaxants in the treatment of myofascial face pain. A literature review. Minerva Stomatol. 2004;53(6):305-13.

3. Vas J, Perea-Milla C, Méndez C, Sánchez Navarro C, León Rubio JM, Brioso M, et al. Efficacy and safety of acupuncture for chronic uncomplicated neck pain: a randomised controlled study. Pain. 2006;126(1-3):245-55.

4. Ritenbaugh C, Hammerschlag R, Calabrese C, Mist S, Aickin M, Sutherland E et al. A pilot whole systems clinical trial of traditional Chinese medicine and naturopathic medicine for the treatment of temporomandibular disorders. J Altern Complement Med. 2008;14(5):475-87.

5. Smith P, Mosscrop D, Davies S, Sloan P, Al-Ani Z. The efficacy of acupuncture in the treatment of temporomandibular joint myofascial pain: a randomised controlled trial. J Dent. 2007;35(3):259-67.

6. Shen YF, Goddard G. The short-term effects of acupuncture on myofascial pain patients after clenching. Pain Pract. 2007;7(3):256-64.

7. Ghoname EA, White PF, Ahmed HE, Hamza MA, Craig WF, Noe CE. Percutaneous electrical nerve stimulation: an alternative to TENS in the management of sciatica. Pain. 1999;83(2):193-9.

8. Hamza M, White PF, Craig WF, Ghoname ES, Ahmed HE, Proctor TJ, et al. Percutaneous electrical nerve stimulation: a novel analgesic therapy for diabetic neuropathic pain. Diabetes Care. 2000;23(3):365-70.

9. Ghoname EA, Craig WF, White PF, Ahmed HE, Hamza MA, Henderson BN, et al Percutaneous electrical nerve stimulation for low back pain: a randomized crossove study. JAMA. 1999;281(9):818-23.

10. Ahmed HE, White PF, Craig WF, Hamza MA, Ghoname ES, Gajraj NM. Use of percutaneous electrical nerve stimulation (PENS) in the short-term management of headache. Headache. 2000;40(4):311-5.

11. Yokoyama M, Sun X, Oku S, Taga N, Sato K, Mizobuchi S, et al. Comparison of percutaneous electrical nerve stimulation with transcutaneous electrical nerve stimulation for long-term pain relief in patients with chronic low back pain. Anesth Analg. 2004;98(6):1552-6.

12. Fonseca DM, Bonfante G, Valle AL, Freitas SF. Diagnóstico pela anamnese da disfunçăo craniomandibular. RGO. 1994;42(1):23-4,27-8.

13. de Lucena LB, Kosminsky M, da Costa LJ, de Góes PS. Validation of the Portuguese version of the RDC/TMD Axis II questionnaire. Braz Oral Res. 2006;20(4):312-7.

14. Ta LE, Dionne RA. Treatment of painful temporomandibular joints with a cyclooxygenase-2 inhibitor: a randomized placebo-controlled comparison of celecoxib to naproxen. Pain. 2004;111(1-2):13-21.

15. La Touche R, Goddard G, De-la-Hoz JL, Wang K, Paris-Alemany A, Angulo-Díaz-Parreño $\mathrm{S}$, et al. Acupuncture in the treatment of pain in temporomandibular disorders: a systematic review and meta-analysis of randomized controlled trials. Clin J Pain. 2010;26(6):541-50.

16. Jung A, Shin BC, Lee MS, Sim H, Ernst E. Acupuncture for treating temporomandibular joint disorders: a systematic review and meta-analysis of randomized, sham-controlled trials. J Dent. 2011;39(5):341-50.

17. List T, Helkimo M. Tenderness and acupuncture points in the masseter muscle: a correlation study. J Craniomandib Disord. 1988;2(3):133-6.

18. Weiner DK, Perera S, Rudy TE, Glick RM, Shenoy S, Delitto A. Efficacy of percutaneous electrical nerve stimulation and therapeutic exercise for older with chronic low back pain: a randomized controll trial. Pain. 2008;140(2):344-57.

19. Cummings M. Percutaneous electrical nerve stimulation--electroacupuncture by another name? A comparative review. Acupunct Med. 2001;19(1):32-5. 